\title{
First report of bats (Mammalia: Chiroptera) from the Gray Fossil Site (late Miocene or early Pliocene), Tennessee, USA
}

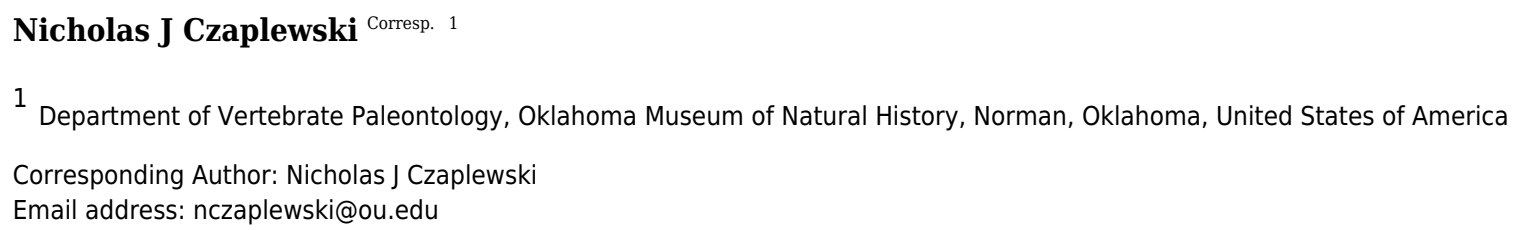

Thousands of vertebrate fossils have been recovered from the Gray Fossil Site, Tennessee, dating to the Miocene-Pliocene boundary. Among these are but eight specimens of bats representing two different taxa referable to the family Vespertilionidae. Comparison of the fossils with Neogene and Quaternary bats reveals that seven of the eight specimens pertain to a species of Eptesicus that cannot be distinguished from recent North American Eptesicus fuscus. The remaining specimen, a horizontal ramus with $\mathrm{m} 3$, is from a smaller vespertilionid bat that cannot confidently be assigned to a genus. Although many vespertilionid genera can be excluded through comparisons, and many extinct named taxa cannot be compared due to nonequivalence of preserved skeletal elements, the second taxon shows morphological similarities to small-bodied taxa with three lower premolar alveoli, three distinct $\mathrm{m} 3$ talonid cusps, and $\mathrm{m} 3$ postcristid showing the myotodont condition. It resembles especially Nycticeius humeralis and small species of Eptesicus. Eptesicus cf. E. fuscus potentially inhabited eastern North America continuously since the late Hemphillian land mammal age, when other evidence from the Gray Fossil Site indicates the presence in the southern Appalachian Mountains of a warm, subtropical, oakhickory-conifer forest having autochthonous North American as well as allochthonous biogeographical ties to eastern Asia and tropical-subtropical Middle America. 
1 FIRST REPORT OF BATS (MAMMALIA: CHIROPTERA) FROM THE GRAY FOSSIL SITE

2 (LATE MIOCENE OR EARLY PLIOCENE), TENNESSEE, USA

3 Nicholas J. Czaplewski

4 Oklahoma Museum of Natural History, 2401 Chautauqua Avenue, University of Oklahoma, 5 Norman, Oklahoma 73072, USA

6 Corresponding author:

$7 \quad$ Nicholas J. Czaplewski

8 Oklahoma Museum of Natural History, 2401 Chautauqua Avenue, University of Oklahoma,

9 Norman, Oklahoma 73072, USA

10 Email address: nczaplewski@ou.edu 
11 FIRST REPORT OF BATS (MAMMALIA: CHIROPTERA) FROM THE GRAY FOSSIL SITE

12 (LATE MIOCENE OR EARLY PLIOCENE), TENNESSEE, USA

13 Nicholas J. Czaplewski

14 Oklahoma Museum of Natural History, 2401 Chautauqua Avenue, University of Oklahoma, 15 Norman, Oklahoma 73072, USA

16 Abstract

17 Thousands of vertebrate fossils have been recovered from the Gray Fossil Site, Tennessee,

18 dating to the Miocene-Pliocene boundary. Among these are but eight specimens of bats

19 representing two different taxa referable to the family Vespertilionidae. Comparison of the fossils

20 with Neogene and Quaternary bats reveals that seven of the eight specimens pertain to a species

21 of Eptesicus that cannot be distinguished from recent North American Eptesicus fuscus. The

22 remaining specimen, a horizontal ramus with $\mathrm{m} 3$, is from a smaller vespertilionid bat that cannot

23 confidently be assigned to a genus. Although many vespertilionid genera can be excluded through

24 comparisons, and many extinct named taxa cannot be compared due to nonequivalence of

25 preserved skeletal elements, the second taxon shows morphological similarities to small-bodied

26 taxa with three lower premolar alveoli, three distinct $\mathrm{m} 3$ talonid cusps, and $\mathrm{m} 3$ postcristid

27 showing the myotodont condition. It resembles especially Nycticeius humeralis and small species

28 of Eptesicus. Eptesicus cf. E. fuscus potentially inhabited eastern North America continuously

29 since the late Hemphillian land mammal age, when other evidence from the Gray Fossil Site

30 indicates the presence in the southern Appalachian Mountains of a warm, subtropical, oak-

31 hickory-conifer forest having autochthonous North American as well as allochthonous

32 biogeographical ties to eastern Asia and tropical-subtropical Middle America. 
33 Introduction

34 The Gray Fossil Site (GFS) is a small but significant late Miocene-early Pliocene

35 vertebrate fossil locality occurring within the Valley and Ridge Zone of the Appalachian

36 Mountains physiographic province. In this region the Valley and Ridge Zone exhibits Paleozoic

37 rocks distorted by numerous broad folds and synclinoria that have also been cut by thrust

38 faulting. The Paleozoic rocks include limestone, dolomite, and marble, providing soluble rocks of

39 the Valley and Ridge karst region, one of the most extensive and important karstic regions in the

40 United States (Middleton and Waltham (1992). Prior to the discovery of GFS in 2000, karstic

41 deposits with Neogene vertebrate fossils including bats were unknown in Tennessee (Corgan and

42 Breitburg 1996). GFS is located about $15 \mathrm{~km} \mathrm{NW}$ of Johnson City, Tennessee, near the small

43 town of Gray in northeasternmost Tennessee. GFS is situated in a small valley and reflects a

44 depositional situation that has been interpreted as multiple sediment-filled sinkholes representing

45 differing ages (at least Paleocene-Eocene and Miocene-Pliocene), and associated with ponds and

46 small streams (Shunk 2011; Whitelaw et al. 2011; Zobaa et al. 2011). One of the sub-basins,

47 GFS-2, has yielded mammalian fossils suggestive of a late Miocene or early Pliocene age,

48 reflecting the late Hemphillian (Hh4) North American Land Mammal Age (Wallace and Wang

49 2004; Schubert and Mead 2011; Mead et al. 2012; Wallace et al. 2014). The diverse paleobiota of

50 GFS-2 includes plant fossils, charcoalified wood, spores, and pollen that indicate a surrounding

51 open-to-dense deciduous forest dominated by oak, hickory, conifer, and vines (including one,

52 Sinomenium, having subtropical-tropical Asian affinities), and subject to occasional drought and

53 fires and browsing by large mammalian herbivores (Liu and Jacques 2010; Zavada 2011; Ochoa

54 and Liu 2011; Ochoa et al. 2012). Non-mammalian vertebrates recovered include bony fishes,

55 salamanders, aquatic turtles, Alligator, snakes, and a beaded lizard, Heloderma (Mead et al.

56 2012). Preservation of biological remains is excellent and even includes abdominal contents and

57 eggs/oocysts of internal parasites of some large mammals (McConnell and Zavada, 2013). 
58 Remains of Alligator suggest a warmer climate than today in this region, with annual low

59 temperatures probably above $5.5^{\circ} \mathrm{C}$ (Shunk 2011). GFS is one of extremely few Neogene

60 vertebrate faunas in interior eastern North America (Janis et al. 2008). Certain members of the

61 GFS fauna help to provide evidence for the relationships between paleontological events and

62 intercontinental connections between eastern North America and Eurasia in the late Neogene

63 (Wallace and Wang 2004; Mead et al. 2012; Doby and Wallace 2014). Although these members

64 of the GFS fauna have been studied previously, specimens of bats have been slow to accumulate.

65 This paper describes the first few specimens of bats yet uncovered at the GFS.

66 Methods

67 The first eight fossils of bats recovered from sedimentary deposits at the Gray Fossil Site

68 by the staff and affiliates of the Gray Fossil Site and East Tennessee State University Museum of

69 Natural History as of 2016 were graciously loaned to the author for study. The fossils were

70 identified by comparison with casts of Neogene North American fossil bats and with skeletal

71 material of recent bats in the Oklahoma Museum of Natural History. Occlusal terminology of the

72 teeth and humeral terminology follow Czaplewski et al. (2008); terminology for anatomical

73 features of a petrosal bone follows Stanek (1933), Henson (1970) and Giannini et al. (2006).

74 Capital letters indicate upper teeth, and lower case letters indicate lower teeth. Measurements of 75 specimens were made at 10X or 20X using an ocular micrometer on an Olympus SZX9

76 stereomicroscope. Abbreviations: apl, anteroposterior length; ETMNH, East Tennessee Museum 77 of Natural History; GFS, Gray Fossil Site.

78 Systematic Paleontology 
79 Order Chiroptera Blumenbach, 1779

80 Family Vespertilionidae Gray, 1821

81 Subfamily Vespertilioninae Gray, 1821

82 Tribe Eptesicini Volleth and Heller, 1994

83 Genus Eptesicus Rafinesque, 1820

84 Eptesicus cf. E. fuscus (Palisot de Beauvois, 1796)

85 (Figs. 1, 2)

87 specimen number 9714, right M1; ETMNH 19286, left edentulous dentary fragment with partial

88 alveoli for p4-m3; ETMNH 19287, left partial dentary with $\mathrm{m} 2$ and condyloid and angular

89 processes; ETMNH 19288, right m2 possibly associated with 19287; ETMNH 9654, partial right

90 petrosal; ETMNH 14022, left distal humerus; ETMNH 9755, left proximal radius.

91 Measurements (in mm): ETMNH 9714, M1 anteroposterior length (apl), 1.8; transverse

92 width, 2.05. ETMNH 19286 depth of dentary beneath posterior alveolus of m1, 1.7. ETMNH

93 19288, right m2 apl, 1.8; trigonid width, 1.1; talonid width, 1.2. ETMNH 19287 left m2 apl, 1.9;

94 trigonid width, 1.1; talonid width, 1.2. ETMNH 14022 distal humerus midshaft diameter, 1.5;

95 greatest transverse distal width, 3.5; extension of trochlea beyond spinous process, 0.3 ; proximo-

96 distal diameter of trochlea (in anterior view), 1.8; anteroposterior diameter of trochlea (in distal

97 view), 2.2; anteroposterior diameter of lateral ridge of capitulum (capitular tail, in lateral view),

98 1.9; transverse width of medial epicondyle from medial edge (lip) of trochlea, 0.6; width of distal

99 articular surface (trochlea to capitular tail), 2.9. ETMNH 9755 proximal radius greatest width, 2.5

$100 \mathrm{~mm}$. 
101 Description:

102 The right upper molar ETMNH 9714 appears to be M1, because its length and width are

103 more nearly equal to one another than in M2s, which are anteroposteriorly shorter and

104 transversely wider (Fig. 1A-C). In occlusal view, these proportions give M1 a rather squarish

105 appearance while M2s are more rectangular. The tooth shows light wear especially on the

106 ectoloph crests. The protocone is tall and about as high as the metacone; paracone is slightly

107 smaller. The preprotocrista extends labially almost to the parastyle. The lingual cingulum is

108 interrupted at the base of the protocone; it extends anteriorly to the level of the base of the

109 paracone, and extends posteriorly around the talonlike swelling and continuing as a

110 metacingulum nearly to the metastyle. As in other vespertilionids there is no real hypocone shelf

111 or hypocone, although the posterolingual corner of the tooth is slightly expanded as a small talon.

112 This talon supports a small crest ("postprotocingulum" of Gunnell et al. [2011]) that is a steeper

113 continuation of the less-inclined postprotocrista. The protofossa is deep. Paraloph and metaloph

114 are absent. The protofossa/trigon basin is open posteriorly. The parastylar fovea is about half the

115 volume of the metastylar fovea, and it has a weaker labial cingulum compared to the better

116 developed labial cingulum of the metastylar fovea. Labially the flexus of the parastylar fovea is

117 deeper than that of the metastylar fovea.

118 The m2s in ETMNH 19287 (Fig. 1F-H) and 19288 are the same size as one another, show

119 myotodonty, have a tiny lingual cingulum restricted to the base of the trigonid valley, and a thick

120 and prominent labial cingulum. The metaconid and entoconid are about the same height, and the

121 entoconid bears a straight entocristid. Both $\mathrm{m} 2 \mathrm{~s}$ from GFS are the size of the $\mathrm{m} 2$ of E. fuscus.

122 The condyloid and angular processes of the dentary are similar in size and shape to those in $E$.

123 fuscus, in which some intraspecific variation occurs among the comparison specimens.

124 The jaw fragment ETMNH 19286 is broken through the anterior alveolus of the p4, and

125 posteriorly it is broken through the posterior alveolus of the m3 (Fig. 1D-E); it is from a large bat, 
126 about the same size as E. fuscus. The edentulous fragment includes the alveoli for a two-rooted

$127 \mathrm{p} 4$. Mesial and slightly lingual to the $\mathrm{p} 4$ anterior alveolus is the bottom of another premolar

128 alveolus (Fig. 1D); this probably represents the socket for the single root of a p3.

129 ETMNH 9654 is a damaged right petrosal missing most of the pars cochlearis and parts of

130 the crista parotica and lateral semicircular canal (Fig. 1I-L). The posterior semicircular canal

131 bears a thin, small partial lamina occurring as a flange along its ventral edge, and the anterior

132 semicircular canal bears a short flangelike laminae near either end. There is no complete lamina

133 capping the area between the three semicircular canals as seen in petrosals of members of the

134 Emballonuridae, Rhinolophidae, and some Molossidae (Morgan et al., in review; Morgan and

135 Czaplewski, in preparation). The opening of the vestibular aqueduct is relatively large and

136 slitlike, with slight breakage around the bony rim. The vestibular aqueduct abruptly tapers funnel-

137 like to a thin duct within the dorsal bone of the common crus. There is an obvious external

138 swelling over the ampulla of the anterior semicircular canal, partly breached by breakage along

139 the prefacial commissure. On the crista parotica the anterior petrosal process is broken off at its

140 base, but the base indicates that the process was thin and flattened. The anterior petrosal process

141 is separated anteriorly from the prefacial commissure by a narrow U-shaped notch. Immediately

142 posterior to the anterior petrosal process, the medial wall of the fossa incudis occurs as a small,

143 smooth-walled indentation, tapering posteriorly and broken along its ventral edge exposing more

144 of the facial sulcus (semicanal for the facial nerve). An overhanging sharp-edged small ridge

145 constricts the posterior end of the fossa incudis, and a small oval depression occurs in its

146 anterodorsal portion that accommodates the crus breve of the incus. The fossa for the stapedius

147 muscle is large and broad. The fenestra cochleae is larger than the fenestra vestibuli. The fenestra

148 cochleae is much wider than high. The cochlear canaliculus is smaller than the fenestra vestibuli.

149 There is a fairly prominent groove for the stapedial artery on the posteroventral lip of the fenestra

150 vestibuli. There is a small tubercle (Fig. 1I, J, K, labeled "tu") ventral to the fenestra cochleae as 
151 seen in several vespertilionids, in Miniopterus, and also resembling that present in a fossil

152 emballonurid from the late Oligocene-early Miocene of Florida (Morgan and Czaplewski, in 153 preparation).

154 The distal humerus ETMNH 14022 represents a moderately large vespertilionid (Fig. 2A-

155 E). The preserved portion of the shaft is nearly straight in anterior view, while the distal end

156 curves gently forward in lateral view. Posteriorly the bone has a relatively deep olecranon fossa

157 (for a bat, in which the olecranon fossa is often absent), while anteriorly it bears a deep, broad

158 coronoid fossa and smaller confluent radial fossa. The ridges of the capitulum are aligned with

159 the long axis of the shaft. The distal articular surface is only slightly offset laterally relative to the

160 shaft, as in most vespertilionids, in that a line drawn to extend distally along the lateral edge of

161 the humeral shaft follows the capitular groove and the entire lateral ridge of the capitulum with

162 capitular tail occurs laterally beyond this line, while a similar line along the medial edge of the

163 shaft follows approximately the medial edge of the trochlea. The trochlea and capitulum are

164 separated by a shallow groove. There is a more pronounced groove between medial and lateral

165 ridges of the capitulum. The spinous process of the medial epicondyle does not extend distally as

166 far as the distal ridge of the trochlea; a small flat to slightly concave distal tip blunts the end of

167 the spinous process. On the medial epicondyle, in medial view, a tiny depression separates the

168 spinous process from a small, more proximally situated, medial process. Laterally there is a deep

169 supra-epicondylar groove between the lateral epicondyle and the capitular tail. The fossae at the

170 medial and lateral ends of the epicondyles are deep.

171 The proximal radius ETMNH 9755 is typical of that of vespertilionids (Fig. 2F-J). On the

172 posterior surface it has two small facets for articulation with the proximal ulna, an oval central

173 one and a separate smaller, curved, medial one. The proximal articular surface shared with the

174 humerus is dominated by the large and moderately deep central groove that accommodates the

175 medial ridge of the humeral capitulum. Lateral to this groove is a small shallowly dished area that 
176 accommodates the lateral ridge of the humeral capitulum. Medial to the central groove is a facet

177 for accommodation of the humeral trochlea. The flexor fossa for insertion of the biceps muscles

178 is deep and narrow; although situated on the medial side of the radius just distal to the head, it is

179 still visible in anterior view. In medial (ventral) view the flexor fossa is closed off proximally by

180 a thin flange of bone but is open distally. The proximal radius is very similar in morphology and

181 size to that of extant E. fuscus.

182 Discussion and Comparisons:

183 In morphological features of the M1, the GFS specimen differs from Corynorhinus,

184 Myotis, Nycticeius, Parastrellus, Perimyotis, and Plionycteris in being larger and more robust and

185 in details of cusp and crest shapes. It differs from the M1s of Antrozous and Lasiurus mainly in

186 that the postprotocrista does not connect to the base of the metacone, and from Simonycteris in

187 having the lingual cingulum absent at the base of the protocone. It is essentially identical to the

188 M1 in modern specimens of Eptesicus fuscus.

189 The crown morphology and size of the $\mathrm{m} 2 \mathrm{~s}$, one of which is still retained within a partial

190 dentary with the ascending ramus, closely match the same elements in E. fuscus. In the

191 edentulous partial dentary ETMNH 19286, no portion of a large canine alveolus is apparent

192 mesially due to breakage, so it is not possible to determine whether more than one small lower

193 premolar was present between the lower canine and the large p4 in this specimen. However,

194 because the preserved alveolar configuration of the ramus fragment and its size and are consistent

195 with those in dentaries of E. fuscus, the specimen is referred to E. cf. E. fuscus along with the

196 teeth and tooth-bearing dentary in the GFS sample.

197 Petrosals of very few extinct late Paleogene and Neogene North American bats have been

198 described in detail; they belong to families other than Vespertilionidae (e.g., Morgan et al., In

199 review; Morgan and Czaplewski, In preparation). By comparison with petrosals of several 
200 families of recent bats available for comparison, the GFS petrosal is representative of the

201 structure in certain vespertilionids. Although exhaustive comparisons were not made throughout

202 the diverse and globally-distributed family, the GFS petrosal resembles that of many

203 vespertilionids in having a flattened anterior petrosal process separated anteriorly from the

204 prefacial commissure by a narrow U-shaped notch, in having the anterior ampulla visible

205 externally as a prominent swelling, and in having the fenestra cochleae much wider than high.

206 Some obvious differences serve to differentiate the Gray Fossil Site petrosal from petrosals of

207 several widespread genera of vespertilionids. The fossil differs from the petrosal of Plecotus in

208 lacking a completely laminated posterior semicircular canal, in having a much larger stapedial

209 fossa, and in possessing an anterior petrosal process. It differs from Corynorhinus in having a less

210 completely laminated posterior semicircular canal, in possessing an anterior petrosal process, and

211 in having a lower fenestra cochleae relative to its width. Compared to Barbastella the fossil has a

212 broader stapedial fossa, a narrow U-shaped notch immediately anterior to the anterior petrosal

213 process instead of a broad connection of the process to the bone near the anterior ampulla, and

214 thin rather than thick bone making up the prefacial commissure bridging the facial canal. It

215 differs from Antrozous in lacking a sharp flange along the length of the anterior semicircular

216 canal (variably developed among individuals of Antrozous pallidus examined) and a curved

217 rather than nearly straight opening of the fenestra cochleae. It differs from Lasiurus in having a

218 narrow U-shaped notch anterior to the anterior petrosal process, a broader stapedial fossa, and a

219 larger opening of the vestibular aqueduct that extends higher along the common crus. The

220 unbroken portion of the pars cochlearis lacks evidence of the broad flange extending medially

221 toward the basioccipital in Nyctalus, Vespertilio, and Lasiurus (some genera and species have the

222 flange limited in extent to the medialmost portion not preserved in the fossil), and bears a rather

223 stout tubercle ventral to the fenestra cochleae that is absent in Nyctalus, Vespertilio, and Myotis.

224 The GFS petrosal further differs from that of Myotis in having a less completely laminated 
225 posterior semicircular canal, a small tubercle ventral to the fenestra cochleae, and a larger, flared

226 opening of the vestibular aqueduct extending higher along the common crus. It differs from the

227 petrosal of Lasionycteris in having an open (unlaminated) posterior semicircular canal. It differs

228 from that of Perimyotis in having a less completely laminated posterior semicircular canal and a

229 small tubercle ventral to the fenestra cochleae. It differs from the petrosal of Nycticeius in having

230 a less completely laminated posterior semicircular canal and a long anterior petrosal process. It

231 differs from that of Pipistrellus in having a tubercle ventral to the fenestra cochleae and a less

232 completely laminated posterior semicircular canal. In morphology the petrosal is a close match

233 with petrosals of E. fuscus, and the size also matches that of E. fuscus. Without comprehensive

234 samples of modern bat petrosals for comparisons, and without assessments of petrosal variation

235 within and among genera and species, it is difficult to judge individual variability in this element

236 and provide a precise identification of ETMNH 9654. Because of its close similarity to the

237 petrosal of modern E. fuscus, and in light of the relative abundance of other craniodental fossils

238 referred to Eptesicus herein, this petrosal is tentatively referred to the same taxon.

239 Few Neogene bats are known in North America by fossil of their humeri. Lawrence

240 (1943) described two genera, Miomyotis and Suaptenos based solely on nearly complete humeri

241 from the early Miocene Thomas Farm locality in Florida. Another Thomas Farm bat, Karstala, is

242 also represented by fossils of its humerus (Czaplewski and Morgan 2000). Lawrence (1943)

243 considered both Miomyotis and Suaptenos to be most closely related to Myotis. The late

244 Oligocene genus Oligomyotis also was established solely upon a distal portion of humerus from

245 Colorado (Galbreath 1962), although the holotype and only known specimen is lost (Czaplewski

246 et al. 1999, 2008). The olecranon fossa is absent or weakly developed in most western

247 hemisphere genera of Vespertilionidae; it is best developed in Lasiurus and Eptesicus. In

248 available characters, the distal humerus from GFS differs most notably from that of most North

249 American bats, including Miomyotis, Suaptenos, Karstala, and Oligomyotis, in having a 
250 relatively well developed olecranon fossa. Lasiurine bats, known in the fossil state in North

251 America back to the late Miocene (Clarendonian land mammal age; Czaplewski et al. 1999,

252 2008), have an even better developed olecranon fossa than Eptesicus and the GFS fossil. As in

253 the available jaws and teeth, the GFS distal humerus most closely resembles that of Eptesicus

254 fuscus.

$255 \quad$ Felten et al. (1973) distinguished European species of Eptesicus from other European

256 vespertilionids in having the distal humerus with a spinous process that does not extend beyond

257 the trochlea, a transition between the trochlea and medial ridge of the capitulum on the joint

258 surface that is concave proximally, and the proximal tip of the trochlea reaches the contour of the

259 epiphysis in anterior view. In the GFS humerus the first two of these characters are met, but the

260 proximal tip of the trochlea does not reach the outline of the epiphysis. The bone is virtually

261 identical to the humerus of modern Eptesicus fuscus in details of shape, except that the notch

262 between the spinous process and distal edge of the trochlea is deeper and more distinct. However,

263 this feature can be individually variable: one of four specimens of modern E. fuscus examined

264 had a shallower notch whereas the other three had no notch in this area. Alternatively, if

265 additional fossils are eventually found that consistently bear the distal notch, they might help

266 determine whether the Hemphillian GFS bat is a distinct species of Eptesicus.

267 Genus and species indeterminate

268 (Fig. 3)

269 Material: ETMNH 19285, right dentary horizontal ramus with $\mathrm{m} 3$ and alveoli for all of 270 the other lower teeth. 
272 trigonid width, and $0.6 \mathrm{~mm}$ in talonid width. Dentary depth below the anterior alveolus of $\mathrm{m} 1$ is

$2731.25 \mathrm{~mm}$. Alveolar length from c1-m3 is $5.0 \mathrm{~mm}$.

274 Description: The ramus is from a small vesper bat, much smaller than E. fuscus. It

275 indicates an animal near the size of the extant eastern North American species Lasiurus borealis.

276 The alveolar formula indicates $3 \mathrm{i}, 1 \mathrm{c}, 2$ or $3 \mathrm{p}, 3 \mathrm{~m}$. The canine alveolus is relatively small. The

277 three lower premolar alveoli are subequal in size, with the first and third equal and the middle

278 one slightly smaller. For the lower premolars these three alveoli ostensibly do not allow a

279 determination of the presence of a single-rooted $\mathrm{p} 3$ and double-rooted $\mathrm{p} 4$ or of three single-rooted

280 lower premolars $\mathrm{p} 2, \mathrm{p} 3, \mathrm{p} 4$. However, in bats with three single-rooted premolars, the p3 root is

281 typically smallest, that of p2 larger, and that of p4 largest, usually much larger than that of the

282 adjacent $\mathrm{p} 3$, whereas in bats with a two-rooted $\mathrm{p} 4$ the roots are nearly equal in size. The $\mathrm{m} 3$ is

283 relatively unreduced with low trigonid cusps and a narrower but relatively wide, basined talonid

284 that retains three distinct and well-developed cusps, hypoconid, entoconid, and hypoconulid. The

$285 \mathrm{~m} 3$ postcristid exhibits clear myotodonty.

286 Discussion and Comparisons: Among recent vespertilionid genera with three root sockets

287 between the lower canine and the first lower molar, there are two possible premolar

288 configurations, a single-rooted $\mathrm{p} 3$ and double-rooted $\mathrm{p} 4(1+2)$, or single-rooted p2, p3, and p4 (1

$289+1+1)$. The premolar alveolar count of $1+2$ is known in Antrozous, Barbastella, Bauerus,

290 Eptesicus, Histiotus, Ia, some Lasiurus, Nycticeius, Otonycteris, Perimyotis, Parastrellus,

291 Rhogeessa, Scotomanes, and Vespertilio, whereas the $1+1+1$ count occurs in Corynorhinus and

292 Idionycteris. Among northern hemisphere Neogene bats of North America and Eurasia, ETMNH

29319285 differs from Ancenycteris, Hanakia, Eptenonnus, Quinetia, and Submyotodon, and from 
294 the extant species (some of which are also known as Quaternary fossils) of Lasionycteris, Myotis, 295 some Lasiurus, Plecotus, Euderma, Scotoecus, and Scotozous in having three lower premolar 296 alveoli. ETMNH 19285 differs from Barbastella, Nyctalus, Scotoecus, and Scotozous in showing 297 myotodonty rather than nyctalodonty of the molar postcristid. It differs from Otonycteris and 298 Scotomanes in having m3 with a well-developed rather than greatly reduced $\mathrm{m} 3$ talonid. ETMNH 29919285 differs from Karstala, Samonycteris, Idionycteris, Histiotus, Ia, Antrozous, Bauerus,

300 Otonycteris, Nyctalus, Scotoecus, Scotomanes, and Scotozous in its much smaller size, and from 301 Parastrellus in its much larger size (although the $\mathrm{m} 3$ has about the same dimensions in both the 302 fossil and Parastrellus hesperus, Parastrellus has the alveolar tooth row length about 5.8 instead 303 of $5.0 \mathrm{~mm}$ ). Compared to Corynorhinus and Idionycteris, premolar alveoli in the GFS fossil are 304 more nearly equal to one another in size rather than having the $\mathrm{p} 4$ alveolus larger than those of $\mathrm{p} 2$ 305 and $\mathrm{p} 3$. Moreover, the $\mathrm{m} 3$ trigonid cusps--especially the protoconid--are distinctly shorter than in 306 Corynorhinus, and the m3 hypoconulid is better developed. Compared to Lasiurus (subgenus 307 Lasiurus), Lasiurus (Dasypterus), Rhogeessa, and Scotomanes, the GFS fossil differs in having a 308 stronger talonid on $\mathrm{m} 3$ with better developed hypoconulid and hypoconid. It has a deeper, more 309 robust horizontal ramus and more robust teeth than Perimyotis subflavus. Comparisons cannot be 310 made with the Neogene vespertilionids Paleptesicus (includes $P$. priscus only; see Horácek 311 2001), Plionycteris, Potamonycteris, Simonycteris, Suaptenos, and Miomyotis because of non312 comparability of available skeletal elements. No distinguishing features of the GFS fossil could 313 be found in comparisons with Nycticeius, the smaller species of Eptesicus (i.e., numerous small

314 Palearctic, Neotropical, Afrotropical, and Indomalayan species), Nycticeinops, Vespertilio,

315 Miostrellus, and Pipistrellus. Because these genera cannot be distinguished from one another

316 based on the morphological features preserved in ETMNH 19285, it is not possible to assign the 317 GFS specimen to a genus. 
319 Discussion

320 Fossils of Eptesicus of several species have been described from the Miocene of Europe

321 (Storch 1999; Rosina and Sinitsa 2014) and from the early Pliocene to Pleistocene in Africa

322 (Gunnell 2010). In North America, Cf. Eptesicus sp. (a quite small vespertilionid) occurred in the

323 late Miocene (late Hemphillian land mammal age) of the Redington fauna, Arizona (Czaplewski

324 1993), while E. ?fuscus was listed in the early Pliocene (early Blancan land mammal age) at Beck

325 Ranch, Texas (Dalquest 1978), Eptesicus sp. in the late Pliocene (late Blancan) at Inglis 1A,

326 Florida (Morgan 1991), and Eptesicus fuscus in the Pliocene (Blancan) in San Bernardino

327 County, California (Czaplewski 1993). The late Miocene species Eptesicus "hemphillensis" from

328 Coffee Ranch, Texas (middle Hemphillian; Dalquest 1983) is taxonomically invalid, although

329 another specimen from Coffee Ranch is inseparable from E. fuscus (see Czaplewski et al. 2008).

330 Eptesicus species are also known from the Pleistocene of South America.

331 The species Eptesicus fuscus has a relatively extensive Pleistocene record and distribution

332 covering much of its modern North American range east of the Rocky Mountains and in Mexico

333 (Kurta and Baker 1990; Faunmap Working Group 1994; Arroyo-Cabrales 2005), in the

334 Quaternary in parts of northern South America within and beyond its present-day range there

335 (Linares 1968; Czaplewski and Cartelle 1998; Lessa et al. 2005; Rodrigues and Ferigolo 2005),

336 and in the Caribbean (Morgan 2001). The genus Eptesicus in the present day is widely distributed

337 in the northern hemisphere (Holarctic biogeographic regions) as far north as the Arctic Circle,

338 and southward through many parts of Eurasia and Africa. In the Neotropical region it extends

339 southward through Central America and South America, south to central Argentina, as well as in

340 northern and southern Africa, and southeastern Asia (northern Indomalayan region). The genus

341 has considerable recent diversity and contains about 25 extant species of small to large body size 
342 for the family (Corbet 1978; Corbet and Hill 1992; Reid 1997; Simmons 2005; Gardner 2007;

343 Happold and Happold 2013; Juste et al. 2013).

344 The living, widespread Eurasian species E. serotinus is very similar in morphology to the

345 North American E. fuscus, and the two species (and possibly other species of the genus) cannot

346 be distinguished by morphological characteristics of skeletal elements. At one time Koopman

347 (1994) synonymized the two species as E. serotinus, but later authors reversed this designation

348 (Simmons 2005). The morphological similarity of the GFS fossils with E. fuscus and E. serotinus

349 could point to the immigration from Europe or Asia of an ancestral Eptesicus, but molecular

350 phylogenetic studies show the two species to have separate origins (Roehrs et al. 2010;

351 Agnarsson et al. 2011; Juste et al. 2013) and an autochthonous origin in North America is likely.

352 For this reason, and because of the very close morphological correspondence to recent $E$. fuscus,

353 I tentatively refer the GFS fossil to E. cf. E. fuscus.

354 In any case, the few GFS fossils cannot address these questions unless better more

355 complete specimens are found. A Miocene biogeographic connection for tropical forest between

356 eastern Asia and western North America via Beringia is already well established (Wolfe 1994a, b;

357 Sirkin and Owens 1998; Reinink-Smith and Leopold 2005). The fossil occurrence at GFS of

358 several vines including Sinomenium and several species of grapes (Vitis) having eastern Asian

359 affinities (Gong et al 2010; Liu and Jacques 2010), as well as the GFS fossil mammals

360 Pristinailurus and Arctomeles, related to the red panda and Eurasian badger (Wallace and Wang

361 2004), respectively, suggest that perhaps the ancestry of E. fuscus should also be looked for in

362 eastern Asia.

363 This report includes the first records of bats from the Gray Fossil Site, and the second

364 record of Eptesicus in the late Neogene of eastern North America, the other being the Florida

365 Pliocene record. Recent bats of the genus Eptesicus occur on six continents and are tolerant of a

366 wide range of habitats and environmental conditions from lowlands to highlands and rain forest 
367 to desert (Emmons and Feer 1997; Reid 1997; Wilson and Ruff 1999; Gardner 2007; Happold

368 and Happold 2013; Ceballos 2014). For example, Eptesicus fuscus itself is widespread in the

369 extant biota of northwestern South America, Central America, many Caribbean Islands, and

370 North America throughout the United States and much of southern Canada. It is a habitat

371 generalist and utilizes a variety of habitats across this broad range (Agosta 2002); foraging

372 habitat is in relatively open vegetation, woodlands, forest, and forest clearings (at higher

373 elevations in tropical mountains, lower in the temperate zone) and roosting (including hibernation

374 in the coldest season) occurs in caves, rock crevices, tree hollows, and human-built structures

375 (Linares 1968; Harvey et al. 2011). As a result, the GFS E. cf. E. fuscus and the second

376 unidentified vespertilionid cannot provide new information relevant to paleoenvironmental

377 interpretations of the GFS; nevertheless, they are consistent with earlier interpretations of

378 subtropical oak-hickory forest for the area in the late Hemphillian. Stable isotopes recovered

379 from GFS browsing mammals suggest that in the late Miocene-early Pliocene there was minimal

380 seasonal variation in temperature and precipitation at GFS (DeSantis and Wallace 2008, 2011).

381 Together with annual low temperatures probably above $5.5^{\circ} \mathrm{C}$ (Shunk 2011) and a predicted

382 minimum average annual temperature of at least $22{ }^{\circ} \mathrm{C}(\mathrm{Mead}$ et al. 2012), these

383 paleoenvironmental conditions suggest that hibernation in the area surrounding GFS and southern 384 Appalachian Mountains might not have been necessary or possible for the bats.

\section{ACKNOWLEDGMENTS}

386 For the invitation to study bat specimens from the Gray Fossil Site and for logistical

387 support and encouragement I thank Jim I. Mead, Blaine W. Schubert, Sandy Swift, and Steven C.

388 Wallace. For the loan of specimens and aid at the GFS and in the ETMNH collection I am

389 grateful to S. C. Wallace and April S. Nye. I thank Brandi Coyner and Janet Braun of the 
390 Oklahoma Museum of Natural History for the loan of recent mammal skeletal material. Steve

391 Westrop allowed use of his bellows camera, Stackshot rig, and stacking software; Roger

392 Burkhalter helped with photographing specimens and rendering images. I thank Ivan Horácek 393 and Gregg Gunnell for providing helpful reviews of the manuscript.

394 LITERATURE CITED

395 Agnarsson, I., C. M. Zambrana-Torrelio, N. P. Flores-Saldana, and L. J. May-Collado. 2011. A 396 time-calibrated species-level phylogeny of bats (Chiroptera, Mammalia). PLoS Currents: 397 http://currents.plos.org/treeoflife/article/a-time-calibrated-species-level-3chrbtx927cxs-5/

398 Agosta, S. J. 2002. Habitat use, diet and roost selection by the big brown bat (Eptesicus fuscus) in 399 North America: a case for conserving an abundant species. Mammal Reviews 32:179-198. 400 Arroyo-Cabrales, J. 2005. Murciélagos fósiles de México y Centroamérica. Abstract of 401 presentation for symposium "Fossil Bats of the Americas" convened by Joaquín Arroyo402 Cabrales and Gisele Lessa at the Second Latin American Congress of Vertebrate 403 404 Paleontology, Rio de Janeiro, Brasil, August 10-12. Boletim de Resumos (AWA Kellner, DDR Henriques, and T Rodrigues, eds.) p. 35-36.

405 Blumenbach, J. F. 1779-1780. Handbuch der Naturgeschichte. Göttingen, Johann Christian 406 Dieterich.

407 Ceballos, G. (ed.) 2014. Mammals of Mexico. Baltimore, Johns Hopkins University Press.

408 Corbet, G. B. 1978. The Mammals of the Palearctic Region: A Taxonomic Review. London, 409 British Museum (Natural History), Cornell University Press.

410 Corbet, G. B., and J. E. Hill. 1992. The Mammals of the Indomalayan Region. Oxford, Oxford $411 \quad$ University Press. 
412 Corgan, J. X., and E. Breitburg. 1996. Tennessee's prehistoric vertebrates. Tennessee Division of $413 \quad$ Geology Bulletin 84:1-170.

414 Czaplewski, N. J. 1993. Late Tertiary bats (Mammalia, Chiroptera) from the southwestern United 415 States. Southwestern Naturalist 38(2):111-118.

416 Czaplewski, N. J., B. E. Bailey, and R. G. Corner. 1999. Tertiary bats (Mammalia: Chiroptera) 417 from northern Nebraska. Transactions of the Nebraska Academy of Sciences 25:83-93.

418 Czaplewski, N. J., and C. Cartelle. 1998. Pleistocene bats from cave deposits in Bahia, Brazil. 419 Journal of Mammalogy 79:784-803.

420 Czaplewski, N. J., and G. S. Morgan. 2000. A new vespertilionid bat (Mammalia: Chiroptera) 421 from the early Miocene (Hemingfordian) of Florida, USA. Journal of Vertebrate $422 \quad$ Paleontology 20(4):736-742.

423 Czaplewski, N. J., G. S. Morgan, and S. A. McLeod. 2008. Chiroptera. P. 174-197 in C. M. Janis, 424 G. F. Gunnell, and M. D. Uhen (eds.) Evolution of Tertiary Mammals of North America, 425 volume 2. Cambridge, Cambridge University Press.

426 Dalquest, W. W. 1978. Early Blancan mammals of the Beck Ranch local fauna of Texas. Journal 427 of Mammalogy 59:269-298.

428 Dalquest, W. W. 1983. Mammals of the Coffee Ranch local fauna Hemphillian of Texas. Pearce429 Sellards Series, Texas Memorial Museum 38:1-41.

430 DeSantis, L. R. G., and S. C. Wallace. 2008. Neogene forests from Appalachians of Tennessee, 431 USA: geochemical evidence from fossil mammal teeth. Palaeogeography, 432 Palaeoclimatology, Palaeoecology 266:59-68.

433 DeSantis, L. R.G., and S. C. Wallace. 2011. Ancient ecology and climate of the Gray Fossil Site. 434 Pp. 19-22 in B. W. Schubert and J. I. Mead (eds.) Gray Fossil Site 10 Years of Research. 435 Don Sundquist Center for Excellence in Paleontology, East Tennessee State University, 436 Johnson City, Tennessee, $98 \mathrm{pp}$. 
437 Doby, J., and S. Wallace. 2014. Systematic review of the shrews (Soricidae) from the Gray Fossil

438 Site, Tennessee, USA. Journal of Vertebrate Paleontology, Program and Abstracts

$439 \quad 2014: 120$.

440 Emmons, L. H., and F. Feer. 1997. Neotropical Rainforest Mammals: A Field Guide, Second

441 Edition. Chicago, University of Chicago Press.

442 Faunmap Working Group. 1994. FAUNMAP: a database documenting late Quaternary

443 distributions of mammal species in the United States. Springfield, Illinois State Museum

444 Scientific Papers 25, nos. 1 and 2, 690 p.

445 Felten, H., A. Helfricht, and G. Storch. 1973. Die bestimmung der europäischen fledermäuse

446 nach der distalen epiphyse des humerus. Senckenbergiana Biologica 54:291-297.

447 Galbreath, E. C. 1962. A new myotid bat from the middle Oligocene of northeastern Colorado.

448 Transactions of the Kansas Academy of Science 65:448-451.

449 Gardner, A. L. (ed.) 2007. Mammals of South America, Volume 1: Marsupials, Xenarthrans,

450 Shrews, and Bats. Chicago, University of Chicago Press.

451 Giannini, N. P., J. R. Wible, and N. B. Simmons. 2006. On the cranial osteology of Chiroptera. I.

452 Pteropus (Megachiroptera: Pteropodidae). Bulletin of the American Museum of Natural

453 History 295:1-134.

454 Gong, F., I. Karsai, and Y.-S. Liu. 2010. Vitis seeds (Vitaceae) from the late Neogene Gray Fossil

455 Site, northeastern Tennessee, U.S.A. Review of Paleobotany and Palynology 162:71-83.

456 Gray, J. E. 1821. On the natural arrangement of vertebrose animals. London Medical Repository, 457 Monthly Journal, and Review 15:296-311.

458 Gunnell, G. F. 2010. Chiroptera. Pp. 581-597 in L. Werdelin and W. J. Sanders (eds.) Cenozoic

459 Mammals of Africa. Berkeley, University of California Press.

460 Gunnell, G. F., T. P. Eiting, and D. Geraads. 2011. New late Pliocene bats (Chiroptera) from Ahl 
462 Happold, M., and D. C. D. Happold (eds.). 2013. Mammals of Africa. Volume IV: Hedgehogs, 463 Shrews, and Bats. London, Bloomsbury Publishing.

464 Harvey, M. J., J. S. Altenbach, and T. L. Best. 2011. Bats of the United States and Canada. 465 Baltimore, Johns Hopkins University Press, 204 p.

466 Henson, O. W., Jr. 1970. The ear and audition. Pp. 181-263 in W. A. Wimsatt (ed.) Biology of 467 Bats Volume II. New York, Academic Press.

468 Horácek, I. 2001. On the early history of vespertilionid bats in Europe: the Lower Miocene 469 record from the Bohemian Massif. Lynx 32:123-154.

470 Janis, C. M., G. F. Gunnell, and M. D. Uhen (eds.) 2008. Evolution of Tertiary mammals of North 471 America, volume 2: small mammals, xenarthrans, and marine mammals. Cambridge, $472 \quad$ Cambridge University Press, 795 p.

473 Juste, J., P. Benda, J. L. Garcia-Mudarra, and C. Ibáñez. 2013. Phylogeny and systematics of Old 474 World serotine bats (genus Eptesicus, Vespertilionidae, Chiroptera): an integrative 475 approach. Zoologica Scripta 42:441-457.

476 Koopman, K. F. 1994. Chiroptera: systematics. In Handbook of Zoology, volume VIII:

477 Mammalia, Part 60. New York, Walter de Gruyter, 217 pp.

478 Kurta, A., and R. H. Baker. 1990. Eptesicus fuscus. Mammalian Species no. 356: 1-10.

479 Lawrence, B. 1943. Miocene bat remains from Florida, with notes on the generic characters of 480 the humerus of bats. Journal of Mammalogy 24:356-369.

481 Lessa, G., C. Cartelle, and M. P. de Aguiar. 2005. The bats (Mammalia, Chiroptera) fossils of 482 Brazil. Abstract of presentation for symposium "Fossil Bats of the Americas" convened 483 by Joaquín Arroyo-Cabrales and Gisele Lessa at the Second Latin American Congress of 484 Vertebrate Paleontology, Rio de Janeiro, Brasil, August 10-12. Boletim de Resumos 485 (AWA Kellner, DDR Henriques, and T Rodrigues, eds.) p. 153-155. 
486 Linares, O. J. 1968. Quirópteros subfósiles encontrados en las cuevas Venezolanas. Parte I.

487 Depósito de la Cueva de Quebrada Honda (Designación de Catastro Ar-1). Boletín de la 488 Sociedad Venezolana de Espeleología 1:119-145.

489 Liu, Y.-S., and F. M. Jacques. 2010. Sinomenium macrocarpum sp. nov. (Menispermaceae) from 490 the Miocene-Pliocene transition of Gray, northeast Tennessee, USA. Review of $491 \quad$ Paleobotany and Palynology 159:112-122.

492 McConnell, S. M., and M. S. Zavada. 2013. The occurrence of an abdominal fauna in an 493 articulated tapir (Tapirus polkensis) from the late Miocene Gray Fossil Site, northeastern Tennessee. Integrative Zoology 8:74-83.

Mead, J. I., B.W. Schubert, S. C. Wallace, and S. L. Swift. 2012. Helodermatid lizard from the Mio-Pliocene oak-hickory forest of Tennessee, eastern USA, and a review of monstersaurian osteoderms. Acta Palaeontologica Polonica 57(1):111-121.

Middleton, J., and T. Waltham. 1992. The Underground Atlas: a gazetteer of the world's cave 499 regions. Enderby, United Kingdom, Promotional Reprint Company Limited, 239 p.

Morgan, G. S. 1991. Neotropical Chiroptera from the Pliocene and Pleistocene of Florida. Bulletin of the American Museum of Natural History 206:176-213.

502 Morgan, G. S. 2001. Patterns of extinction in West Indian bats. P. 369-407 in C. A. Woods and F. 503 E. Sergile, eds. Biogeography of the West Indies: patterns and perspectives. Boca Raton, $504 \quad$ Florida, CRC Press.

505 Morgan, G.S., N.J. Czaplewski, and N.B. Simmons. In review. A new mormoopid bat from the 506 Oligocene (Whitneyan and early Arikareean) of Florida, and phylogenetic relationships of 507 the major clades of Mormoopidae (Mammalia: Chiroptera). Bulletin of the American $508 \quad$ Museum of Natural History.

509 Morgan, G.S., and N.J. Czaplewski. In preparation. New bats in the tropical family 510 Emballonuridae (Mammalia: Chiroptera) from the Oligocene and Miocene of Florida, 
511 with a review of Florida Tertiary chiropteran faunas. Bulletin of the Florida Museum of $512 \quad$ Natural History.

513 Ochoa, D., M. Whitelaw, Y.-S. Liu, and M. Zavada. 2012. Palynology of Neogene sediments at 514 the Gray Fossil Site, Tennessee, USA: floristic implications. Review of Palaeobotany and $515 \quad$ Palynology 184:36-48.

516 Ochoa-Lozano, D., and Y.-S. Liu. 2011. In search of the greener side of the Gray Fossil Site: 517 reconstructing plants. Pp. 57-60 in B. W. Schubert and J. I. Mead (eds.) Gray Fossil Site 51810 Years of Research. Don Sundquist Center for Excellence in Paleontology, East 519 Tennessee State University, Johnson City, Tennessee, 98 pp.

520 Palisot de Beauvois, A. M. F. J. 1796. Catalogue Raisonne du Muséum, de Mr. C. W. Peale. $521 \quad$ Philadelphia, Pennsylvania, S. H. Smith, Parent.

522 Rafinesque, C. S. 1820. Annals of Nature; or Annual Synopsis of New Genera and Species of 523 Animals, Plants, \&c., Discovered in North America. First annual number, for 1820. 524 Lexington, Kentucky, T. Smith.

525 Reid, F. A. 1997. A Field Guide to the Mammals of Central America and Southeast Mexico. New $526 \quad$ York, Oxford University Press.

527 Reinink-Smith, L. M., and E. B. Leopold. 2005. Warm climate in the late Miocene of the south 528 coast of Alaska and the occurrence of Podocarpaceae pollen. Palynology 29:205-262.

529 Rodrigues, P. H., and J. Ferigolo. 2005. Dados preliminares sobre os Chiroptera do Quaternário 530 do estado do Rio Grande do Sul, Brasil. Abstract of presentation for symposium "Fossil 531 Bats of the Americas" convened by Joaquín Arroyo-Cabrales and Gisele Lessa at the 532 Second Latin American Congress of Vertebrate Paleontology, Rio de Janeiro, Brasil, 533 August 10-12. Boletim de Resumos (AWA Kellner, DDR Henriques, and T Rodrigues, $534 \quad$ eds.) p. 232-233. 
535 Roehrs, Z. P., J. B. Lack, and R. A. Van Den Bussche. 2010. Tribal phylogenetic relationships

536 within Vespertilioninae (Chiroptera: Vespertilionidae) based on mitochondrial and nuclear

537 sequence data. Journal of Mammalogy 91:1073-1092.

538 Rosina, V. V., and M. V. Sinitsa. 2014. Bats (Chiroptera, Mammalia) from the Turolian of the 539 Ukraine: phylogenetic and biostratigraphic considerations. Neues Jahrbuch für Geologie $540 \quad$ und Paläontologie, Abhandlungen 272:147-166.

541 Schubert, B. W., and J. I. Mead (eds.) 2011. Gray Fossil Site 10 Years of Research. Johnson City, 542 Tennessee, Don Sundquist Center for Excellence in Paleontology, East Tennessee State $543 \quad$ University, 98 p.

544 Shunk, A. 2011. The Gray Fossil Site paleoclimate: implications for global warming. Pp. 69-72 in

545 B. W. Schubert and J. I. Mead (eds.) Gray Fossil Site 10 Years of Research. Don

546 Sundquist Center for Excellence in Paleontology, East Tennessee State University, 547 Johnson City, Tennessee, $98 \mathrm{pp}$.

548 Simmons, N. B. 2005. Chiroptera. Pp. 312-529 in D. E. Wilson and D. M. Reeder (eds.) Mammal 549 Species of the World: A taxonomic and geographic reference, $3^{\text {rd }}$ edition. Baltimore, Johns $550 \quad$ Hopkins University Press.

551 Sirkin, L., and J. P. Owens. 1998. Palynology of latest Neogene (middle Miocene to late 552 Pliocene) strata in the Delmarva Peninsula of Maryland and Virginia. Northeastern 553 Geology and Environmental Sciences 20:117-132.

554 Stanek, V.J. 1933. K topografické a srovnávací anatomii sluchového orgánu nasich chiropter.

555 Praze [Prague], Nákladem Ceské Akademie Ved a Umení, 67 pp. + 9 plates.

556 Storch, G. 1999. Order Chiroptera. Pp. 81-90 in G. E. Rössner and K. Heissig (eds.) The Miocene 557 Land Mammals of Europe. Munich, Verlag Friederich Pfeil. 
558 Volleth, M., and K.-G. Heller. 1994. Phylogenetic relationships of vespertilionid genera

559 (Mammalia: Chiroptera) as revealed by karyological analysis. Zeitschrift für Zoologische $560 \quad$ Systematik und Evolutionsforschung 32:11-34.

561 Wallace, S. C., and X. Wang. 2004. Two new carnivores from an unusual late Tertiary forest biota 562 in eastern North America. Nature 431:556-559.

563 Wallace, S. C., B. Schubert, J. Mead, R. Short, J. Doby, and S. Swift. 2014. Recent finds from the 564 latest Miocene/early Pliocene Gray Fossil Site lagerstätten of eastern Tennessee, southern 565 Appalachians, USA. Journal of Vertebrate Paleontology, Program and Abstracts, $566 \quad 2014: 251$.

567 Whitelaw, M. J., A. Shunk, and C. M. Liutkus. 2011. Formation, structure, and fill of the Gray 568 Fossil Site Basin. Pp. 87-92 in B. W. Schubert and J. I. Mead (eds.) Gray Fossil Site 10 569 Years of Research. Don Sundquist Center for Excellence in Paleontology, East Tennessee $570 \quad$ State University, Johnson City, Tennessee, 98 pp.

571 Wilson, D. E., and S. Ruff (eds.) 1999. The Smithsonian Book of North American Mammals. $572 \quad$ Washington, Smithsonian Institution Press.

573 Wolfe, J. A. 1994a. Tertiary climatic changes at middle latitudes of western North America.

$574 \quad$ Palaeogeography, Palaeoclimatology, Palaeoecology 108:207-216.

575 Wolfe, J. A. 1994b. An analysis of Neogene climates in Beringia. Palaeogeography, $576 \quad$ Palaeoclimatology, Palaeoecology 108:207-216.

577 Zavada, M. S. 2011. Plant community structure and landscape reconstruction, late Miocene, Gray 578 Fossil Site. Pp. 97-98 in B. W. Schubert and J. I. Mead (eds.) Gray Fossil Site 10 Years of 579 Research. Don Sundquist Center for Excellence in Paleontology, East Tennessee State $580 \quad$ University, Johnson City, Tennessee, 98 pp.

581 Zobaa, M. K., M. S. Zavada, M.J. Whitelaw, A. J. Shunk, and F. E. Oboh-Ikuenobe. 2011. 582 Palynology and palynofacies analyses of the Gray Fossil Site, eastern Tennessee: their 
583 role in understanding the basin-fill history. Palaeogeography, Palaeoclimatology,

$584 \quad$ Palaeoecology 308:433-444. 
586 Fig. 1. Cranial elements of Eptesicus cf. E. fuscus from the Gray Fossil Site, Tennessee. A-C, 587 right M1 (ETMNH 9714) in occlusal (A, coated with ammonium chloride to reduce glare), 588 lingual (B), and posterior (C) views. D-E, left edentulous dentary fragment with alveoli for p4589 m3 (ETMNH 19286, coated) in occlusal (D), and labial (E) views. F-H, left partial dentary with $590 \mathrm{~m} 2$ (ETMNH 19287, coated) in occlusal (F), labial (G), and lingual (H) views. I-L, right petrosal 591 (ETMNH 9654) in lateral (I), ventral (J), posterior (K), and dorsal (endocranial, L) views.

592 Abbreviations for petrosal: ant, anterior; asc, anterior semicircular canal; cc, cochlear canaliculus 593 (plugged with sediment); cp, crista parotica (largely broken away); cr, common crus; dors, dorsal; 594 fc, fenestra cochleae; fi, medial wall of fossa incudis; fs, facial sulcus (and semicanal for facial 595 nerve plugged with sediment); fv, fenestra vestibuli; gsa, groove for stapedial artery; ji, jugular 596 incisure; lat, lateral; 1sc, lateral semicircular canal (dotted line indicates path of chamber exposed 597 through broken crista parotica); pa, base of broken anterior petrosal process; post, posterior; psc, 598 posterior semicircular canal; sa, subarcuate fossa; sf, stapedial fossa; tu, tubercle ventral to 599 fenestra cochleae; va, opening of vestibular aqueduct (plugged with sediment).

600 Fig. 2. Postcranial elements of Eptesicus cf. E. fuscus from the Gray Fossil Site, Tennessee. Left 601 distal humerus (ETMNH 14022; coated with ammonium chloride) in anterior (A), posterior (B), 602 lateral (C), medial (D), and distal (E) views. Left proximal radius (ETMNH 9755) in anterior (F), 603 posterior $(\mathrm{G})$, lateral $(\mathrm{H})$, medial $(\mathrm{I})$, and proximal $(\mathrm{J})$ views.

604 Fig. 3. Vespertilionidae, genus indeterminate, right horizontal ramus with m3 (ETMNH 19285) 605 from the Gray Fossil Site, Tennessee, in occlusal (A), lingual (B), and labial (C) views. Specimen 606 is coated with ammonium chloride for photography. 

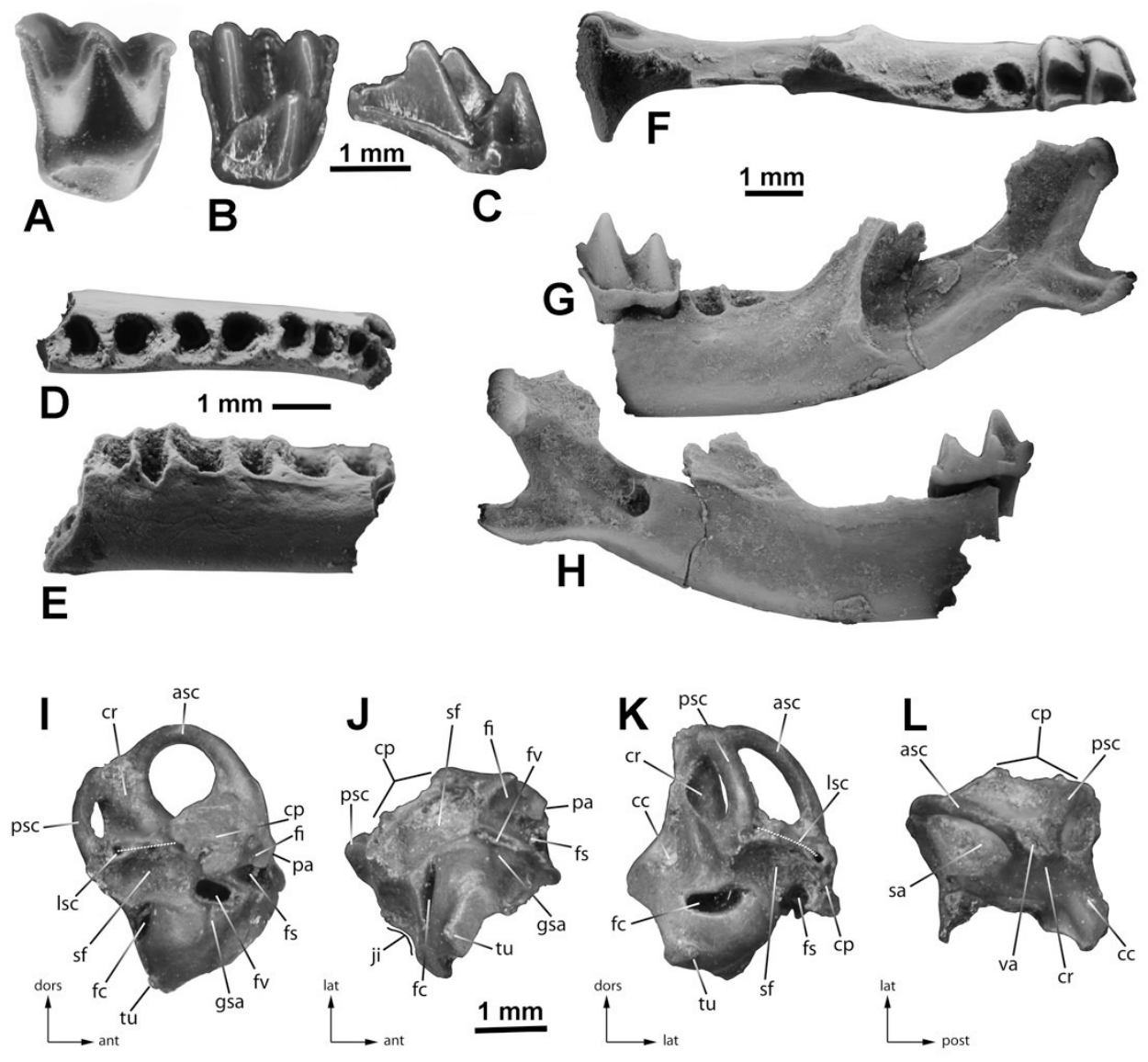

607 Fig. 1. Cranial elements of Eptesicus cf. E. fuscus from the Gray Fossil Site, Tennessee. A-C,

608 right M1 (ETMNH 9714) in occlusal (A, coated with ammonium chloride to reduce glare),

609 lingual (B), and posterior (C) views. D-E, left edentulous dentary fragment with alveoli for p4-

$610 \mathrm{~m} 3$ (ETMNH 19286, coated) in occlusal (D), and labial (E) views. F-H, left partial dentary with

611 m2 (ETMNH 19287, coated) in occlusal (F), labial $(\mathrm{G})$, and lingual $(\mathrm{H})$ views. I-L, right petrosal

612 (ETMNH 9654) in lateral (I), ventral (J), posterior (K), and dorsal (endocranial, L) views.

613 Abbreviations for petrosal: ant, anterior; asc, anterior semicircular canal; cc, cochlear canaliculus

614 (plugged with sediment); cp, crista parotica (largely broken away); cr, common crus; dors, dorsal;

615 fc, fenestra cochleae; fi, medial wall of fossa incudis; fs, facial sulcus (and semicanal for facial

616 nerve plugged with sediment); fv, fenestra vestibuli; gsa, groove for stapedial artery; ji, jugular

617 incisure; lat, lateral; 1sc, lateral semicircular canal (dotted line indicates path of chamber exposed 
618 through broken crista parotica); pa, base of broken anterior petrosal process; post, posterior; psc,

619 posterior semicircular canal; sa, subarcuate fossa; sf, stapedial fossa; tu, tubercle ventral to

620 fenestra cochleae; va, opening of vestibular aqueduct (plugged with sediment). 


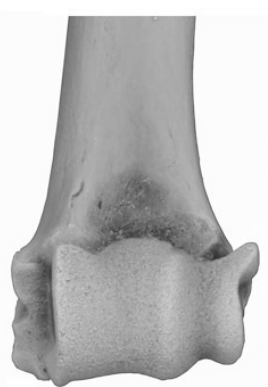

A

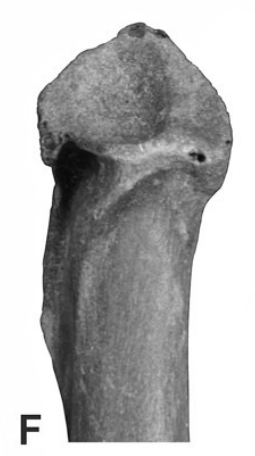

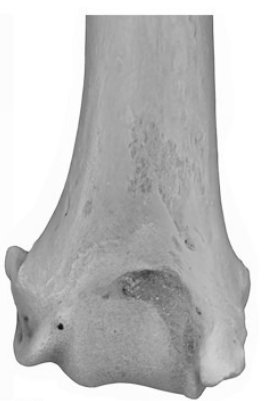

B

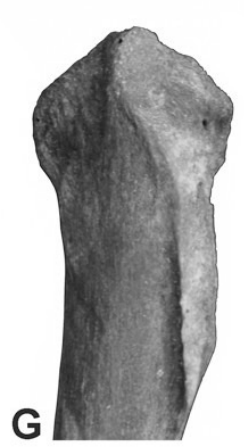

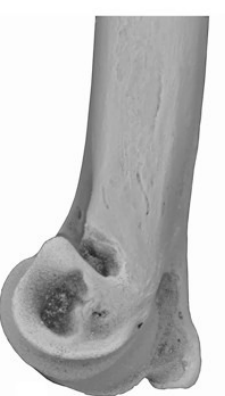

C
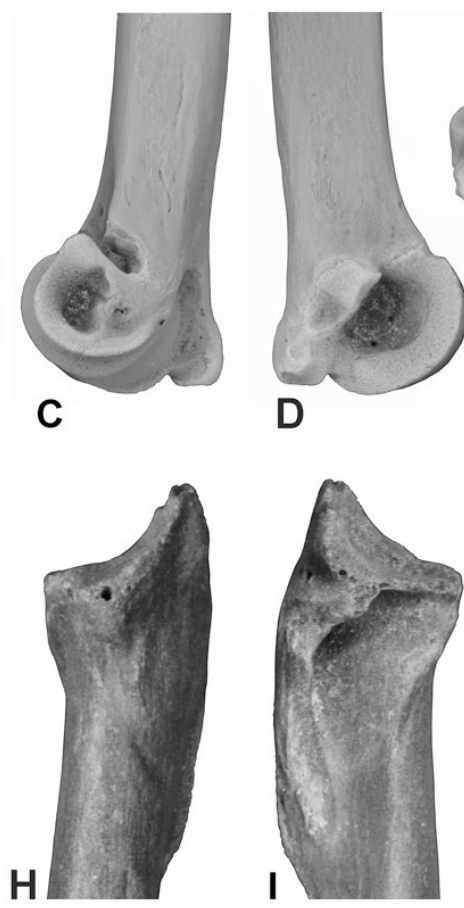

D

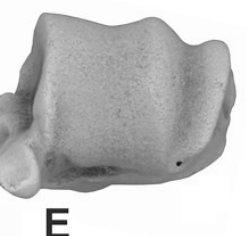

E

$1 \mathrm{~mm}$

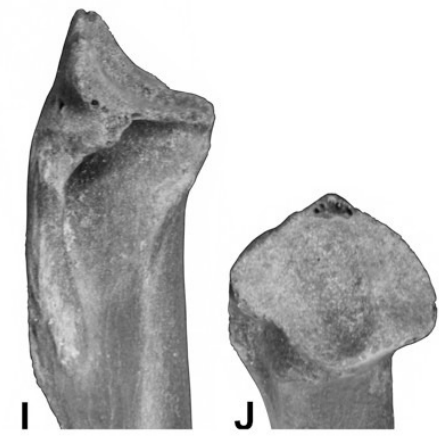

621 Fig. 2. Postcranial elements of Eptesicus cf. E. fuscus from the Gray Fossil Site, Tennessee. Left 622 distal humerus (ETMNH 14022; coated with ammonium chloride) in anterior (A), posterior (B), 623 lateral (C), medial (D), and distal (E) views. Left proximal radius (ETMNH 9755) in anterior (F), 624 posterior $(\mathrm{G})$, lateral $(\mathrm{H})$, medial $(\mathrm{I})$, and proximal $(\mathrm{J})$ views. 

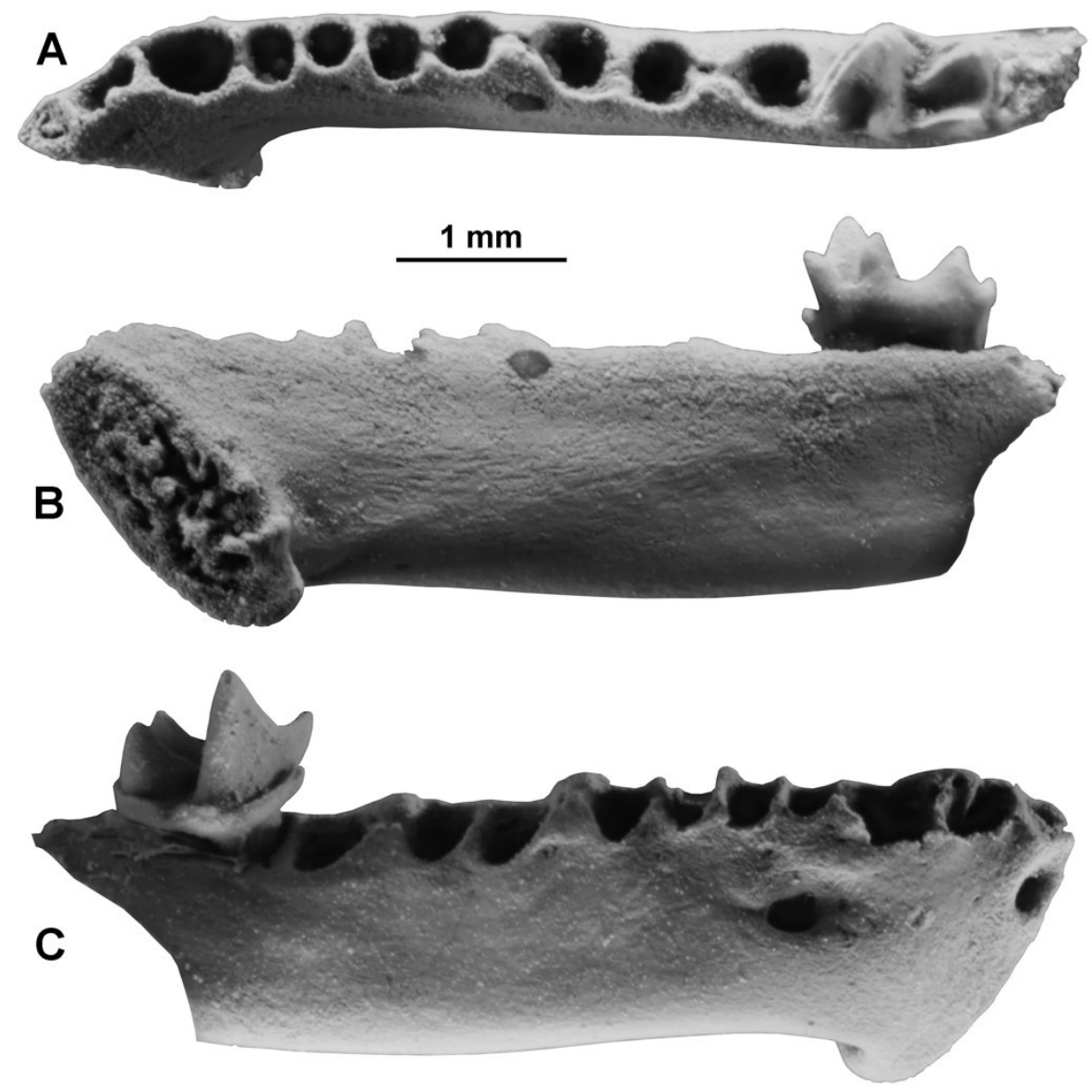

625 Fig. 3. Vespertilionidae, genus indeterminate, right horizontal ramus with m3 (ETMNH 19285)

626 from the Gray Fossil Site, Tennessee, in occlusal (A), lingual (B), and labial (C) views. Specimen 627 is coated with ammonium chloride for photography. 